\title{
Effect of Long-Term Application of Inorganic and Organics on Soil Aggregate Fractions in Double Rice Cropping System
}

\author{
A. Krishna Chaitanya ${ }^{1 *}$, Shrikant Badole ${ }^{1}$, Dhaneshwar Padhan ${ }^{1}$, \\ Shyam Prasad Majumder ${ }^{1}$ and Ch. Sreenivas ${ }^{2}$
}

\author{
${ }^{1}$ Bidhan Chandra Krishi Viswavidyalaya, Kalyani-741235, West Bengal, India \\ ${ }^{2}$ Acharya N G Ranga Agricultural University, Rajamahendravaram - 533 101, A.P., India \\ *Corresponding author
}

\section{A B S T R A C T}

\begin{tabular}{|l|}
\hline Ke y w o r d s \\
$\begin{array}{l}\text { Soil aggregates, mean } \\
\text { weight diameter, } \\
\text { aggregate associated } \\
\text { carbon, and double } \\
\text { rice cropping }\end{array}$ \\
\hline Article Info \\
\hline $\begin{array}{l}\text { Accepted: } \\
\text { 30 July } 2017 \\
\text { Available Online: } \\
\text { 10 August } 2017\end{array}$ \\
\hline
\end{tabular}

Keywords

Soil aggregates, mean weight diameter, aggregate associated rice cropping

\section{Introduction}

Analyses of physical structure of soil are usually done using physical fractionation methods, which are based on the premise that the association of the soil particles and their spatial arrangement play a key role in the function of SOM (Gregorich et al., 2006). The aggregation is a means to both protect and conserve soil organic carbon (SOC) and allow the stored organic matter to function as a reservoir of plant nutrients. Crop cultivation is known to adversely affect the distribution and stability of soil aggregates and reduces SOC stock in soils (Six et al., 2000; Kong et al., 2005). The impacts of cultivation on $\mathrm{C}$ stock have commonly been observed to be restricted mostly to surface soils and/or to root zone depth (Paustian et al., 1997b). However, different crop species have different effects on soil aggregation and $\mathrm{C}$ accumulation with varying soil depth. Altering soil physicochemical properties by management practices may increase one or more of the protective attributes which ultimately increases $\mathrm{C}$ in soils provided $\mathrm{C}$ inputs to soil do not decrease.

The distribution of soil organic carbon (SOC) in different aggregate size classes (i.e. micro, meso, and macroaggregates) may affect soil erosion and more rapid loss may occur from 
macroaggregates than microaggregates (Eynard et al., 2005). Tillage disturbs large aggregates more than smaller aggregates, making SOC more susceptible to mineralization (Six et al., 1998). Clay particles have a higher protective effect on chemical and biophysical processes of carbon stabilization (Christensen, 1996). Clay plus silt serves as a fixed capacity level (Hassink and Whitmore, 1997) while the combination of micro, meso, and macro aggregated carbon provide an additional variable capacity. The former is soil specific while the latter tends to be contingent on both amount of carbon input and soil type.

Cultivated soils have a smaller WSA within $>2 \mathrm{~mm}$ and 1-2 $\mathrm{mm}$ aggregate size fractions but a greater aggregation in $<0.25 \mathrm{~mm}$ size fraction than the fallow is found. Tillage operations may enhance the susceptibility of aggregates to disruption by wet-dry cycles that lead to a loss of C-rich macro aggregate fractions. The MWD and GMD have smaller values in the cultivated than the fallow soils indicating more disturbances through tillage and lower accumulation as well as protection of SOC in macro-aggregates (Gupta Choudhury et al., 2010).

The smaller aggregates in the cropland soils are therefore consistent with the lower SOM content (Emadi et al., 2008). Loss of the larger aggregate sizes in cropland could also be due to tillage rapidly destroying live and decaying plant roots, fungal hyphae, earthworms and termites. These factors tend to favor the formation of larger sized aggregates (Tisdale and Oades 1982).Size distribution of aggregates is affected by the change in land use and management (Spaccini et al., 2001). The loss of large sized water stable aggregates under cultivation was also associated with a significant reduction in stability as measured by the MWD. The stability of intact WSA showed higher values in uncultivated soils than in cultivated soils.
There were no significant differences in MWD between forest and pasture soils (Emadi et al., 2008) Although the importance of organic matter to improve soil aggregate stability is well known, the experiments showing the beneficial effects of organic matter on aggregate stability have been varied. For instance, some workers (Christensen 1986) found a significant correlation between organic matter and aggregate stability.

\section{Materials and Methods}

\section{Site description}

A long-term experiment was established in the year 1989, at the experimental farm of the Andhra Pradesh Rice Research and Regional Agricultural Research Station, Maruteru, Andhra Pradesh $\left(16.37^{\circ} \mathrm{N}\right.$ and $16.40^{\circ} \mathrm{N}$, and $81.44^{\circ} \mathrm{E}$ and $81.46^{\circ} \mathrm{E}$ and $8.2 \mathrm{~m}$ above mean sea level) with double rice (Oryza sativa L.). Crop was sown every year during kharif i.e. mid June to mid-October and rabi i.e. mid November to mid-March. The area receives, on an average, annual rainfall of approximately $1200 \mathrm{~mm}$. The mean annual minimum and maximum temperatures were $10.0^{\circ} \mathrm{C}$ and $37.6^{\circ} \mathrm{C}$, respectively.

The soil was classified as inceptisol, with clay loam texture developed from the deltaic sediments of Godavari River. The site had the soil moisture and temperature regimes of udic and mesic/thermic, respectively.

Two rice (Oryza sativa L.) crops (varieties: MTU-2067, 1061, 1010) were grown annually in the experiment. The experiment was laid out in randomized complete block design with three replications and consisted of the following treatments: (i) control (plots without NPK fertilizers and organics), (ii) $50 \%$ NPK (45:30:30), (iii) 50\% NPK + 50\% $\mathrm{N}$ - green manure (GM-Calotropis sps.), (iv) $50 \% \mathrm{NPK}+50 \% \mathrm{~N}$ - farmyard manure, (v) 
$50 \% \mathrm{NPK}+25 \% \mathrm{~N}-$ green manure (Calotropis sps.) $+25 \% \mathrm{~N}$ - farmyard manure, (vi) farmyard manure $\left(10 \mathrm{t} \mathrm{ha}^{-1}\right)$, (vii) $100 \%$ $\mathrm{NPK}+$ farmyard manure $\left(5 \mathrm{t} \mathrm{ha}^{-1}\right)$, (viii) $100 \% \mathrm{~N}$ and (ix) 100\% NPK (90:60:60).

\section{Aggregate analysis and structural indices}

Two sets of six nested sieves with 2000, 1000, 500, 250, 100 and $53 \mu \mathrm{m}$ diameter size class were used for the separation of water stable aggregates and subsequent calculation of different structural indices. Aggregate separation was done by using wet sieving apparatus (Yoder, 1936). After removing visible pieces of crop residues and roots from the field-moist soil samples, aggregates ranging in diameter from 2000 to $5000 \mu \mathrm{m}$ were obtained from the air-dried bulk soil that had been broken apart by hand before airdrying for the wet sieving procedure. Exactly $100 \mathrm{~g}$ of soil aggregates $(2000$ to $5000 \mu \mathrm{m})$ in duplicate was slaked by submerging it in deionized water placing on top $2000 \mu \mathrm{m}$ sieve for a while at room temperature. Water stable aggregates were then separated by moving the sieves up and down in a Yoder apparatus for 30 minutes. After correcting sand content in all the aggregates by dispersion with sodium hexametaphosphate, soil aggregate indices were calculated. Aggregates were then fractioned into coarse macro aggregates (CMacA, >2000 $\mu \mathrm{m}$ ), mesoaggregates (MesoA, 250-2000 $\mu \mathrm{m}$ ) and coarse microaggregates (CMicA, 100-250 $\mu \mathrm{m}$ ). The sum of aggregates $>250 \mu \mathrm{m}$ was clubbed as macroaggregates (MacA) while aggregates $<250 \mu \mathrm{m}$ grouped into microaggregates (MicA). With the data of soil aggregates and primary particles the following soil aggregate indices were calculated.

\section{Water stable aggregates}

From the weight of the soil particles (Aggregates + primary particles) in each size group, its proportion to the total sample weight was determined. Water stable aggregates (WSA) was the mass of stable aggregates divided by the total aggregate (stable + primary particles) mass as

Water stable aggregates
$=\left[\frac{(\text { Weight of soil }+ \text { sand }) \mathrm{i}-(\text { Weight of sand)i }}{\text { Weight of sample }}\right]$

Where, $i$ denotes the size of the sieve. The percentage weight of water stable macroaggregates is the summation of soil aggregate-size fractions $>250 \mu \mathrm{m}$; while the percentage weight of water stable microaggregates are those retained in $<250$ $\mu \mathrm{m}$.

\section{Aggregate ratio}

Aggregate ratio (AR) is denoted by

Aggregate ratio

$=\left[\frac{(\text { Aggregatesretained in }>250 \mu \mathrm{m})}{(\text { Aggregatesretained in }<250 \mu \mathrm{m})}\right]$

\section{Mean weight diameter}

After correction of sand content, the amount of aggregates remaining in each size fraction was used to calculate the mean weight diameter (MWD) of the water stable aggregates following van Bavel (1949) as:

Mean weight diameter $(\mathrm{mm})=\frac{\sum_{\mathrm{i}=1}^{\mathrm{n}} X i W i}{\sum_{\mathrm{i}=1}^{\mathrm{n}} W i}$

Where, $\mathrm{n}$ is the number of fractions (100-250, 250-500, 500-1000, 1000-2000, > $2000 \mu \mathrm{m}$, $X i$ is the mean diameter $(\mu \mathrm{m})$ of the sieve size class $(0.175,0.375,0.75,1.5$ and $2.0 \mathrm{~mm})$ and $W i$ is the weight of soil $(\mathrm{g})$ retained on each sieve. 


\section{Geometric mean diameter}

Geometric mean diameter (GMD) an exponential index of aggregate stability was expressed as:

$\exp \left[\frac{\sum_{i=1}^{\mathrm{n}} W i \log X i}{\sum_{\mathrm{i}=1}^{\mathrm{n}} W i}\right]$

Where, $\mathrm{n}$ is the number of fractions same as MWD size, $X i$ is the mean diameter ( $\mathrm{mm}$ ) of the sieve size class same as MWD size and $W i$ is the weight of soil $(\mathrm{g})$ retained on each sieve.

\section{Percent aggregate stability}

The index percent aggregate stability or degree of aggregation (AS) of soil was calculated as:

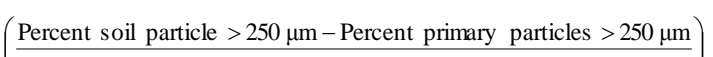
Percent primary particles $<250 \mu \mathrm{m}$

\section{Readily oxidisable organic carbon (OC)}

The oxidizable organic carbon (OC) was determined by Walkley and Black wet oxidation method (Walkley and Black, 1934). One-half $\mathrm{g}$ of ground $(<2.0 \mathrm{~mm})$ soil was placed in a $500 \mathrm{ml}$ Erlenmeyer flask to which $10 \mathrm{ml}$ of $1.0 \mathrm{~N} \mathrm{~K}_{2} \mathrm{Cr}_{2} \mathrm{O}_{7}$ was first added, followed by $20 \mathrm{ml}$ concentrated sulphuric acid.

After half an hour of the reaction under dark, the excess dichromate was determined by titrating against $0.5 \mathrm{~N} \mathrm{Fe}\left(\mathrm{NH}_{4}\right)_{2}\left(\mathrm{SO}_{4}\right)_{2} .6 \mathrm{H}_{2} \mathrm{O}$. The amount of dichromate consumed by the soil was used to calculate the amount of OC based on the theoretical value of $1.0 \mathrm{ml} 1.0 \mathrm{~N}$ $\mathrm{K}_{2} \mathrm{Cr}_{2} \mathrm{O}_{7}$ oxidises $3.0 \mathrm{mg} \mathrm{C}$.

\section{Statistical analysis}

Means of three replicates and standard errors of the means were calculated for all the pools of soil organic carbon (on dry weight basis). The data were analysed using randomized block design (RBD). Statistical analysis was performed by DOS-based SPSS version 12.0. The SPSS procedure was used for analysis of variance (ANOVA) to determine the statistical significance of treatments as well as of cropping systems. Two factor factorial ANOVA was used to determine the existence of interaction effect between treatments and cropping systems. Simple correlation coefficients and regression equations were also developed to evaluate relationships between the response variables using the same statistical package. The 5.0\% probability level is regarded as statistically significant.

\section{Results and Discussion}

\section{Water stable aggregates and structural indices}

The total water stable aggregates (WSA) in the experimental soils ranged from 70.4 to 94.9\% under different treatments. Among the treatments, RDF+FYM had the highest value of different size distributions of water stable aggregates (WSA) (>2000 $\mu \mathrm{m}, 2000-1000$ $\mu \mathrm{m}, 1000-500 \mu \mathrm{m}, 500-250 \mu \mathrm{m}, 250-100 \mu \mathrm{m})$ followed by $50 \%$ RDF+GM > $50 \%$ $\mathrm{RDF}+\mathrm{FYM}>\mathrm{FYM}>50 \% \mathrm{RDF}+\mathrm{GM}+\mathrm{FYM}$ $>\mathrm{RDF}>50 \% \mathrm{RDF}>\mathrm{N}>$ control (Table 1). The mesoaggregates, MesoA (2000-250 $\mu \mathrm{m})$ comprised of $2.0-5.1 \%$ of total WSA compared to $91.6-96.8 \%$ as coarse macro aggregates $(\mathrm{CMacA},>2000 \mu \mathrm{m})$ and 0.26 $2.35 \%$ as coarse micro aggregates, (CMicA, $250-100 \mu \mathrm{m})$.

Irrespective of the treatments, the mesoaggregates (MesoA, 250-2000 $\mu \mathrm{m}$ ) 
comprised of $4.2 \%$ of the total WSA compared to $94.6 \%$ as coarse macro aggregates (CMacA, > 2000 $\mu \mathrm{m})$ and $1.3 \%$ as coarse micro aggregates, (CMicA, 250-100 $\mu \mathrm{m})$. Again, among the mesoaggregates, the 1000-2000 $\mu \mathrm{m}$ fraction exhibited a higher value followed by 500-1000 and 250-500 $\mu \mathrm{m}$ fractions constituting, on an average, 2.1, 1.2 and $0.9 \%$ of the total mesoaggregates.

Application of organics alone and with inorganics significantly improved the mesoaggregate formation compared to the control. Contrarily, the proportion of micro aggregates decreased significantly $(\mathrm{p}<0.05)$ with the application of FYM compared with treatments with combination of organics and inorganics (Table 1). This indicated a higher formation of bigger aggregates with the supplementation of organics. Similar results also were observed by Huang et al., (2010) and Bandyopadhyay et al., (2010).

The organic matter is classified as an important binding agent for aggregation and is responsible for the formation and stability of soil aggregates (Tisdall and Oades. 1982) through biotic mechanism (Schjonning et al., 2006). The added organics could supply additional fresh organic residues (water soluble and hydrolysable substrates) and $\mathrm{C}$ to the soil resulting in production of microbial polysaccharides that increase aggregate cohesion. This explained the observed progressive increase in aggregate stability to mechanical breakdown. Positive effects of green manure and FYM application on aggregate stability have been reported in a number of studies (Bandyopadhyay et al., 2010; Singh et al., 2007). The proportion of large macro aggregates within the total soil aggregates is the most important fraction to evaluate the effect of management practices on soil aggregation, because it exerts a strong influence on the mean weight diameter (MWD), a comprehensive index for evaluating soil aggregation (Jiao et al., 2006).
Again, higher crop residue- $\mathrm{C}$ might have an effect on aggregate stability as plant roots are important binding agents at the scale of macro aggregates (Six et al., 2004). The presence of soil microbial biomass may also influence aggregate formation (Six et al., 2005). FYM applied soils exhibited higher values of aggregate indices. The variations in structural indices among the treated organics might also be influenced by their bio-chemical compositions.

Results showed that the mean weight diameter was significantly $(\mathrm{p}<0.05)$ higher in soils under FYM (2.08 $\mathrm{mm})$ compared to other treatments. Geometric mean diameter (GMD) also exhibited similar trend which ranged from 1.32 to $1.42 \mathrm{~mm}$. Aggregate ratio (AR) showed similar trend, with the highest values in soils under FYM treatment (8.76) but lowest values in soil under control (2.40). Aggregate stability (\%) was significantly (p < 0.05) higher in soils under FYM (93.8\%) compared to control, but at par with other treatments. FYM treated soils showed significantly higher MWD, GMD, AR and AS than those under the other treatments (Table 2). Gupta Choudhury (2011) and Datta (2016) also reported similar findings.

\section{Aggregate associated carbon fractions}

The aggregate associated $\mathrm{C}$ in different sized fractions is presented in Table 4. Incorporation of organics like GM and FYM alone and with inorganics significantly $(\mathrm{p}<0.05)$ increased $\mathrm{C}$ concentration in different sized aggregates over the other treatments. The maximum amount of SOC was retained in coarse micro $(100-250 \mu \mathrm{m})$ and fine micro aggregate $(53-100 \mu \mathrm{m})$ sized fractions followed by $>2000 \mu \mathrm{m}$ and 500$1000 \mu \mathrm{m}$ sized fractions. Total macroaggregate associated carbon was higher under RDF+FYM, while total micro aggregate associated carbon was higher under FYM treatments. 
Table.1 Influence of treatments on distribution of water stable aggregates into different size fractions at surface layer $(0-15 \mathrm{~cm})$

\begin{tabular}{|c|c|c|c|c|c|c|c|}
\hline \multirow[b]{3}{*}{ Treatment } & \multicolumn{7}{|c|}{ \% Water stable aggregates } \\
\hline & \multirow[b]{2}{*}{$\begin{array}{l}\text { CMacA } \\
>2000 \mu \mathrm{m}\end{array}$} & \multicolumn{3}{|c|}{ MesoA } & \multirow[b]{2}{*}{$\begin{array}{l}\text { Total macro } \\
\text { aggregates }\end{array}$} & \multirow[b]{2}{*}{$\begin{array}{l}\text { CMicA } \\
\text { 250-100 } \mu \mathrm{m}\end{array}$} & \multirow{2}{*}{$\begin{array}{l}\text { Total water } \\
\text { stable } \\
\text { aggregates }\end{array}$} \\
\hline & & $\begin{array}{l}2000-1000 \\
\mu \mathrm{m}\end{array}$ & $\begin{array}{l}\text { 1000-500 } \\
\mu \mathrm{m}\end{array}$ & $\begin{array}{l}\text { 500-250 } \\
\mu \mathrm{m}\end{array}$ & & & \\
\hline $50 \% \mathrm{RDF}$ & $79.77^{\mathrm{ab}}$ & $2.18^{\mathrm{bcd}}$ & $1.03^{\mathrm{bc}}$ & $0.58^{\mathrm{bc}}$ & $83.55^{\mathrm{a}}$ & $1.01^{\mathrm{b}}$ & $84.56^{\mathrm{b}}$ \\
\hline $50 \% \mathrm{RDF}+\mathrm{GM}$ & $86.03^{\mathrm{a}}$ & $1.39^{\text {cde }}$ & $0.87^{\mathrm{bc}}$ & $0.49^{\mathrm{bc}}$ & $88.78^{\mathrm{a}}$ & $2.02^{\mathrm{a}}$ & $90.80^{\mathrm{ab}}$ \\
\hline $50 \% \mathrm{RDF}+\mathrm{FYM}$ & $82.38^{\mathrm{a}}$ & $3.76^{\mathrm{a}}$ & $1.86^{\mathrm{a}}$ & $0.88^{\mathrm{ab}}$ & $88.88^{\mathrm{a}}$ & $1.08^{\mathrm{b}}$ & $89.96^{\mathrm{ab}}$ \\
\hline FYM & $85.36^{\mathrm{a}}$ & $2.23^{\mathrm{bc}}$ & $0.88^{\mathrm{bc}}$ & $0.57^{\mathrm{bc}}$ & $89.04^{\mathrm{a}}$ & $0.83^{\mathrm{bc}}$ & $89.87^{\mathrm{ab}}$ \\
\hline $\mathrm{RDF}+\mathrm{FYM}$ & $88.01^{\mathrm{a}}$ & $3.03^{\mathrm{ab}}$ & $0.35^{\mathrm{c}}$ & $1.41^{\mathrm{a}}$ & $92.80^{\mathrm{a}}$ & $2.06^{\mathrm{a}}$ & $94.86^{\mathrm{a}}$ \\
\hline $\mathrm{N}$ & $70.80^{\mathrm{bc}}$ & $0.91^{\text {cde }}$ & $1.15^{\mathrm{ab}}$ & $0.93^{\mathrm{ab}}$ & $73.79^{\mathrm{b}}$ & $0.19^{\mathrm{c}}$ & $73.98^{\mathrm{c}}$ \\
\hline RDF & $82.56^{\mathrm{a}}$ & $1.71^{\text {bcde }}$ & $0.90^{\mathrm{bc}}$ & $0.65^{\mathrm{bc}}$ & $85.82^{\mathrm{a}}$ & $0.45^{\mathrm{bc}}$ & $86.27^{\mathrm{ab}}$ \\
\hline
\end{tabular}

Different small letters within the same column show the significant difference at $\mathrm{p}=0.05$ according to Duncan Multiple Range Test for separation of mean

Table.2 Influence of treatments on aggregate indices of experimental soils at 0-15 cm soil depth

\begin{tabular}{|l|c|c|c|c|}
\hline \multicolumn{1}{|c|}{ Treatment } & MWD (mm) & GMD (mm) & Aggregate Ratio & Aggregate Stability (\%) \\
\hline Control & $1.94^{\mathrm{c}}$ & $1.32^{\mathrm{d}}$ & $2.40^{\mathrm{c}}$ & $54.35^{\mathrm{b}}$ \\
\hline $50 \%$ RDF & $1.98^{\mathrm{ab}}$ & $1.35^{\mathrm{bc}}$ & $5.10^{\mathrm{abc}}$ & $87.22^{\mathrm{a}}$ \\
\hline $50 \%$ RDF+ GM & $2.01^{\mathrm{b}}$ & $1.37^{\mathrm{b}}$ & $9.39^{\mathrm{a}}$ & $93.28^{\mathrm{a}}$ \\
\hline $50 \%$ RDF+FYM & $1.96^{\mathrm{c}}$ & $1.34^{\mathrm{cd}}$ & $8.00^{\mathrm{a}}$ & $92.63^{\mathrm{a}}$ \\
\hline $50 \%$ RDF+GM+FYM & $2.01^{\mathrm{b}}$ & $1.36^{\mathrm{bc}}$ & $7.04^{\mathrm{abc}}$ & $92.66^{\mathrm{a}}$ \\
\hline FYM & $2.08^{\mathrm{a}}$ & $1.42^{\mathrm{a}}$ & $8.76^{\mathrm{a}}$ & $93.81^{\mathrm{a}}$ \\
\hline RDF+FYM & $1.98^{\mathrm{ab}}$ & $1.35^{\mathrm{bc}}$ & $8.14^{\mathrm{a}}$ & $68.10^{\mathrm{b}}$ \\
\hline N & $1.96^{\mathrm{ab}}$ & $1.33^{\mathrm{cd}}$ & $2.93^{\mathrm{bc}}$ & $90.93^{\mathrm{a}}$ \\
\hline RDF & $1.99^{\mathrm{ab}}$ & $1.35^{\mathrm{bc}}$ & $7.21^{\mathrm{ab}}$ & $92.05^{\mathrm{a}}$ \\
\hline
\end{tabular}

Different small letters within the same column show the significant difference at $\mathrm{p}=0.05$ according to Duncan Multiple Range Test for separation of mean 
Table.3 Percent distribution of aggregate associated $\mathrm{C}$ into different aggregate fractions and percent change over $50 \%$ RDF (values within the bracket)

\begin{tabular}{|l|l|l|l|}
\hline \multirow{2}{*}{ Treatment } & \multicolumn{3}{c|}{ \% Total aggregate associated C } \\
\cline { 2 - 4 } & \multicolumn{1}{|c|}{ Cmac AC } & MesoAC & micAC \\
\hline $50 \%$ RDF & 12.7 & 36.3 & 51.0 \\
\hline $50 \%$ RDF+ GM & $12.6(4.69)$ & $36.1(5.10)$ & $51.3(6.54)$ \\
\hline $50 \%$ RDF+FYM & $13.3(9.69)$ & $37.5(8.03)$ & $49.2(4.10)$ \\
\hline $50 \%$ RDF+GM+FYM & $13.1(6.57)$ & $36.6(4.69)$ & $50.3(2.65)$ \\
\hline
\end{tabular}

Table.4 Aggregate associated $\mathrm{C}$ under different size fractions under different treatment

\begin{tabular}{|c|c|c|c|c|c|c|c|c|c|}
\hline \multirow{4}{*}{ Treatment } & \multicolumn{9}{|c|}{ Size fraction $(\mu \mathrm{m})$} \\
\hline & \multicolumn{5}{|c|}{ Macro aggregated $\mathrm{C}\left(\mathrm{g} \mathrm{kg}^{-1}\right)$} & \multicolumn{4}{|c|}{ Micro aggregated $\mathrm{C}\left(\mathrm{g} \mathrm{kg}^{-1}\right)$} \\
\hline & \multirow{2}{*}{$\begin{array}{c}\text { CMacAC } \\
>2000\end{array}$} & \multicolumn{3}{|c|}{ MesoAC } & \multirow{2}{*}{$\begin{array}{c}\text { Total } \\
\text { Macro } \\
\text { AC }\end{array}$} & \multirow{2}{*}{$\begin{array}{c}\text { CMicAC } \\
100-250\end{array}$} & \multirow{2}{*}{$\begin{array}{c}\text { FMicAC } \\
53-100\end{array}$} & \multirow{2}{*}{$\begin{array}{c}\text { (Silt+clay) } \\
\text { AC }<53\end{array}$} & \multirow{2}{*}{$\begin{array}{c}\text { Total } \\
\text { Micro } \\
\text { AC }\end{array}$} \\
\hline & & $1000-2000$ & $500-1000$ & $250-500$ & & & & & \\
\hline Control & $20.53^{c}$ & $18.97^{\mathrm{d}}$ & $20.06^{\mathrm{c}}$ & $19.61 \mathrm{c}$ & $79.17 d$ & $24.65^{b}$ & $50.72^{\mathrm{a}}$ & $18.56^{\mathrm{c}}$ & $93.94^{\mathrm{a}}$ \\
\hline $50 \% \mathrm{RDF}$ & $21.68^{\mathrm{bc}}$ & $20.46^{\mathrm{bcd}}$ & $21.30^{\mathrm{bc}}$ & $20.12^{c}$ & $83.57^{\mathrm{bcd}}$ & $23.94^{\mathrm{b}}$ & $43.04^{\mathrm{a}}$ & $19.85^{\mathrm{ab}}$ & $86.83^{\mathrm{a}}$ \\
\hline $50 \% \mathrm{RDF}+\mathrm{GM}$ & $22.70^{\mathrm{ab}}$ & $21.78^{\mathrm{ab}}$ & $21.70^{\mathrm{b}}$ & $21.56^{\mathrm{b}}$ & $87.75^{\mathrm{ab}}$ & $25.57^{\mathrm{b}}$ & $46.94^{\mathrm{a}}$ & $19.99^{\mathrm{ab}}$ & $92.50^{\mathrm{a}}$ \\
\hline $50 \% \mathrm{RDF}+\mathrm{FYM}$ & $23.78^{\mathrm{a}}$ & $22.29^{\mathrm{a}}$ & $22.09^{b}$ & $22.47^{\mathrm{ab}}$ & $90.64^{\mathrm{a}}$ & $25.70^{\mathrm{b}}$ & $41.74^{\mathrm{a}}$ & $20.35^{\mathrm{ab}}$ & $87.79^{\mathrm{a}}$ \\
\hline $50 \% \mathrm{RDF}+\mathrm{GM}+\mathrm{FYM}$ & $23.11^{\mathrm{a}}$ & $21.14^{\mathrm{ab}}$ & $21.95^{\mathrm{b}}$ & $21.70^{\mathrm{b}}$ & $87.90^{\mathrm{ab}}$ & $24.58^{\mathrm{b}}$ & $44.76^{\mathrm{a}}$ & $19.78^{\mathrm{ab}}$ & $89.13^{\mathrm{a}}$ \\
\hline FYM & $21.32^{\mathrm{c}}$ & $20.67^{\mathrm{abc}}$ & $21.14^{\mathrm{bc}}$ & $21.38^{\mathrm{b}}$ & $84.51^{\mathrm{bc}}$ & $36.26^{\mathrm{a}}$ & $41.99^{\mathrm{a}}$ & $19.31^{\mathrm{bc}}$ & $97.56^{\mathrm{a}}$ \\
\hline $\mathrm{RDF}+\mathrm{FYM}$ & $23.51^{\mathrm{a}}$ & $22.02^{\mathrm{ab}}$ & $24.01^{\mathrm{a}}$ & $23.08^{\mathrm{a}}$ & $92.62^{\mathrm{a}}$ & $23.22^{\mathrm{b}}$ & $43.66^{\mathrm{a}}$ & $19.92^{\mathrm{ab}}$ & $86.81^{\mathrm{a}}$ \\
\hline $\mathrm{N}$ & $20.80^{c}$ & $19.33^{\mathrm{cd}}$ & $20.41^{\mathrm{c}}$ & $20.02^{\mathrm{c}}$ & $80.55^{\mathrm{cd}}$ & $23.24^{\mathrm{b}}$ & $51.45^{\mathrm{a}}$ & $19.26^{\mathrm{bc}}$ & $93.95^{\mathrm{a}}$ \\
\hline RDF & $21.01^{\mathrm{c}}$ & $19.48^{\mathrm{cd}}$ & $20.47^{\mathrm{c}}$ & $19.99^{c}$ & $80.95^{\mathrm{cd}}$ & $20.32^{\mathrm{b}}$ & $52.08^{\mathrm{a}}$ & $20.59^{\mathrm{a}}$ & $92.99^{a}$ \\
\hline
\end{tabular}

Different small letters within the same column show the significant difference at $\mathrm{p}=0.05$ according to Duncan Multiple Range Test for separation of mean 
Fig.1 Relationship between cumulative carbon inputs and C associated with different sized aggregates

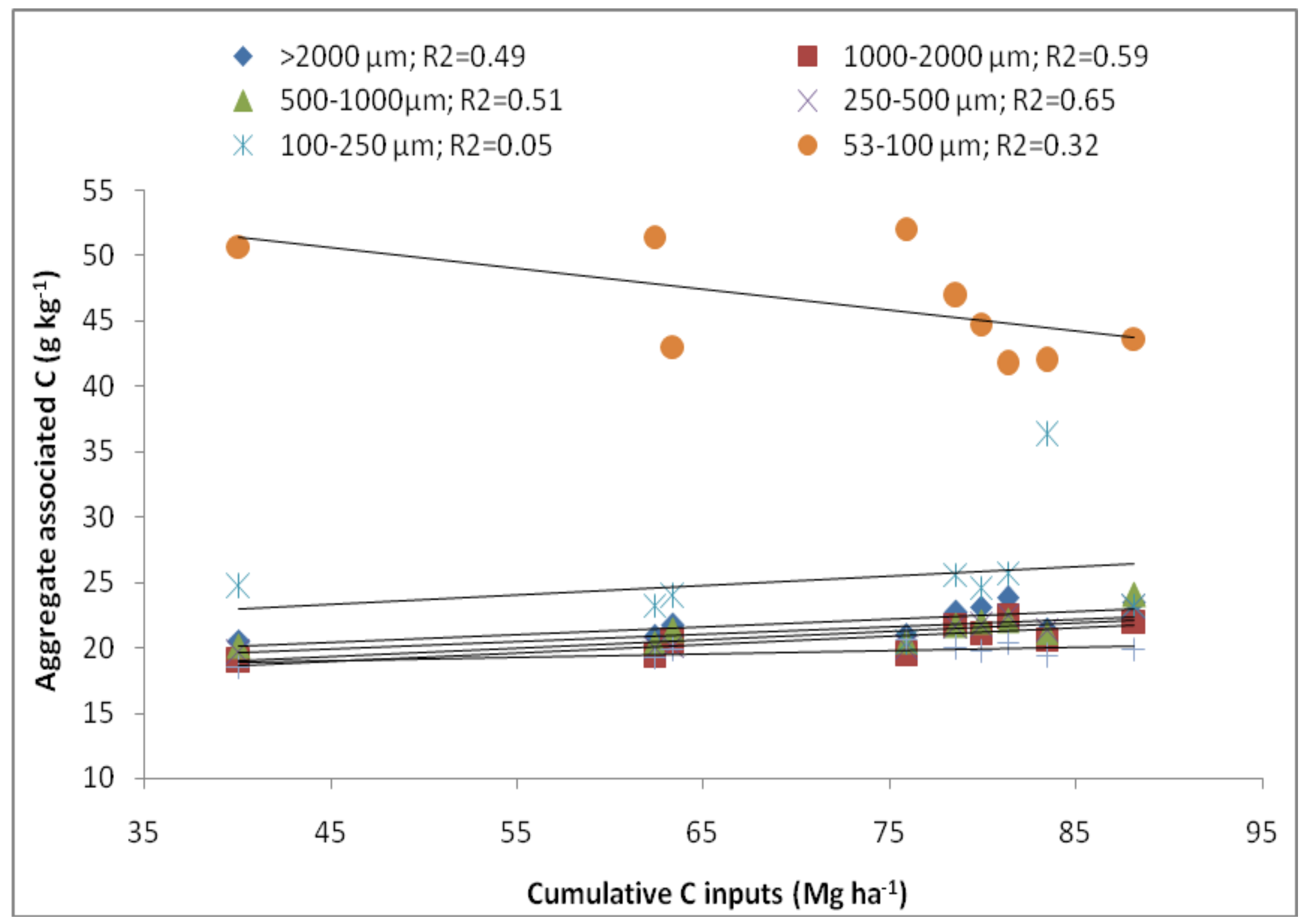


Of the total aggregate associated $\mathrm{C}$, micro aggregates $(<250 \mu \mathrm{m})$ had higher amounts (51.7\%) compared to macro aggregates (> $250 \mu \mathrm{m}, 48.3 \%)$.Application of organics increased $\mathrm{C}$ accumulation in different aggregates, the effect was more pronounced with microaggregates than macroaggregates.

Irrespective of the treatments, a maximum amount of $\mathrm{C}$ was found with mesoaggregate fractions (250- $2000 \mu \mathrm{m}, 58.64-69.11 \mathrm{~g} \mathrm{~kg}^{-1}$ ) followed by fine micro aggregates (53-100 $\left.\mu \mathrm{m}, \quad 41.74-52.08 \mathrm{~g} \mathrm{~kg}^{-1}\right)$, coarse micro aggregates (100-250 $\left.\mu \mathrm{m}, 20.32-36.26 \mathrm{~g} \mathrm{~kg}^{-1}\right)$, coarse macro aggregates (> $2000 \mu \mathrm{m}, 20.53$ $\left.23.78 \mathrm{~g} \mathrm{~kg}^{-1}\right)$ and (silt + clay) sized aggregates $\left(<53 \mu \mathrm{m}, 18.56-20.59 \mathrm{~g} \mathrm{~kg}^{-1}\right)$ in a decreasing order, constituting, on an average, 35.8, 26.2, $14.3,12.5$ and $11.2 \%$, respectively, of the total aggregate associated $\mathrm{C}$ (Table 4).

Aggregate associated $\mathrm{C}$ strongly influences $\mathrm{C}$ sequestration and dynamics of $\mathrm{C}$ cycling in soils. Following 24 years of continuous cropping with different management practices, the experimental soils demonstrated preferential sequestration of $\mathrm{SOC}$ in the meso-aggregate fraction $(250-2000 \mu \mathrm{m})$.

In fact, such sequestration was more with particles of decreasing sizes. A higher surface area for smaller particles may be responsible for this. Christensen (1986) and Kong et al., (2005) also reported similar results. Gupta Choudhury (2011) and Datta (2016) also reported similar findings in Indian subcontinent.

An attempt was made to find out if application of organics in the form of green manure, farmyard manure or their combination could influence the distribution of carbon among macro, meso and micro sized aggregates. On an average, about 51, 36 and $13 \%$ of the aggregate associated $\mathrm{C}$ was allocated to micro, meso and macro sized fractions. These values, however, did not change significantly due to the application of any of the above three sources of organic applied. Results thus indicated that applied carbon found its way to different size aggregates proportional to their native distribution in soils (Table 3 ).

A positive linear relationship was observed between the cumulative $C$ inputs into the soils (during the whole period of experimentation) and the aggregate associated C (Fig 1). Such relationship was stronger particularly with the $\mathrm{C}$ associated with the aggregate size fractions of $250-500 \mu \mathrm{m}\left(\mathrm{R}^{2}=0.65\right)$. This indicated that smaller particles with greater surface area may be responsible for scavenging a sizable amount of $\mathrm{C}$ in micro aggregates. Kong et al., (2005) and Majumder et al., (2007) also reported similar results. However, there was a little influence of increasing $\mathrm{C}$ inputs was observed for $\mathrm{C}$ associated with aggregates of 250-1000 and $<53 \mu \mathrm{m}$ size.

Application of organics had immense effect on soil aggregation and $\mathrm{C}$ sequestration. Mesoaggregates shared the maximum proportion of aggregate associated C (35.8\%) followed by fine micro, coarse micro, coarse macro aggregates and silt + clay fractions constituting $26.2,14.3,12.5$ and $11.2 \%$, respectively.

Application of organics has no effect on relative distribution of aggregate associated carbon into different size fractions. Thus, it can be concluded that even under hot semiarid region of the country, growing of double rice system in Inceptisol with balanced fertilization or $\mathrm{C}$ supplementation through FYM/GM caused a net $C$ sequestration. Hence, in this regions external application of carbon through different organics (FYM/GM) is necessary to improve carbon content in soils and maintain sustainable crop production/yields. 


\section{References}

Bandyopadhyay, P.K., Saha, S., Mani, P.K. and Mandal, B. 2010. Effect of organic inputs on aggregate associated organic carbon concentration under long-term rice-wheat cropping system. Geoderma 154: 379-386.

Christensen, B.T., 1986. Straw incorporation and soil organic matter in macroaggregates and particle size separates. Journal of Soil Science 37: 125-135.

Christensen, B.T., 1996. Carbon in primary and secondary organomineral complexes. In: Carter, M.R., Stewart, B.A. (Eds.), Structure and Organic Matter Storage in Agricultural Soils. Lewis Publ., Boca Raton, FL, pp. 97165

Datta, A., 2016. Stabilization of organic carbon and its saturation deficit in soils under different agro-ecological zones in India. Ph.D. thesis, Bidhan Chandra Krishi Viswavidyalaya, WestBengal.

Emadi, M., Emadi, M., Majid, B., Hamed, F. and Mahboub, S. 2008. Effect of Land Use Change on Selected Soil Physical and Chemical Properties in North Highlands of Iran. Journal of Applied Sciences 8: 496-502.

Eynard, A., Schumacher, T.E., Lindstrom, M.J., Malo, D.D., 2005. Effects of agricultural management systems on soil organic carbon in aggregates of Ustolls and Usterts. Soil Tillage Research. 81, 253-263.

Gregorich, E.G., Beare, M.H., McKim, U.F. and Skjemstad, J.O. 2006. Chemical and biological characteristics of physically uncomplexed organic matter. Soil Science Society of America Journal. 70, 975-985.

Gupta Choudhury, S., Bandyopadhyay, P.K., Mallick, S. and Sarkar, S. 2010. Soil aggregation as affected by cultivation under low and upland situations. Journal of the Indian Society of Soil Science 58 (4): 371-375.

Gupta Chowhury, S., 2011. Pathways of Carbon Sequestration in Soils under Different Agro-ecological Zones in India using Long-term Fertility Experiments. Ph.D. thesis, Bidhan Chandra Krishi Viswavidyalaya, WestBengal.

Hassink, J., Whitmore, A.P., 1997. A model of the physical protection of organic matter in soils. Soil Science Society of America Journal. 61, 131-139

Huang, S., Peng, X., Huang, Q. and Zhang, W. 2010. Soil aggregation and organic carbon fractions affected by long-term fertilization in a red soil of subtropical China. Geoderma 154: 364-369.

Jiao, Y., Whalen J.K. and Hendershot, W.H. 2006. No-tillage and manure applications increase aggregation and improve nutrient retention in a sandyloam soil. Geoderma 134: 24-33

Kong, A.Y.Y., Six, J., Bryant, D.C., Denison, R.F. and Kessel, C. van. 2005. The relationship between carbon input, aggregation, and soil organic carbon stabilization in sustainable cropping systems. Soil Science Society of America Journal 69: 1078-1085.

Majumder, B., Mandal, B., Bandyopadhyay, P.K. and Chaudhury, J. 2007. Soil organic carbon pools and productivity relationships for 34 year old rice-wheatjute agroecosystem under different fertilizer treatments. Plant Soil 297: 5367.

Paustian, K., Collins, H.P. and Paul, E.A. 1997b. Management controls on soil carbon. In: Paul, E.A., Paustian, K., Elliot E.T., Cole, C.V. (eds.), Soil Organic Matter in Temperate Agroecosystems: Long-term Experiments in north America. CRC press, Boca Raton, FL, pp.15-42. 
Schjonning, P., Munkholm, L.J. and Elmholt, S. 2006. Crop rotation and animal manure effects on soil. I. Organic carbon and tilth formation. Summary 7750: Organic eprints. http://org prints.org/7750/.3

Singh, G., Jalota, S.K. and Singh, Y. 2007. Manuring and residue management effects on physical properties of a soil under the rice-wheat system in Punjab, India. Soil and Tillage Research 94: 229-238.

Six, J., Elliott, E.T., Paustian, K., Doran, J.W., 1998. Aggregation and soil organic matter accumulation in cultivatedandnative grasslandsoils. Soil Science Society of America Journal. 62, 1367-1377.

Six, J., Paustian, K., Elliott, E.T. and Combrink, C. 2000. Soil structure and organic matter: I. Distribution of aggregate size classes and aggregateassociated carbon. Soil Science Society of American Journal 64: 681-689.

Six, J., Thomas, J.C., Brahamsha, B., Lemoine, Y. and Partensky, F. 2004. Photophysiology of the marine cyanobacterium Synechococcussp. WH8102, a new model organism. Aquatic Microbial Ecology 35: 17-29.

Six, J., Worden, A.Z., Rodriguez, F., Moreau, H. and Partensky, F. 2005. New insights into the nature and phylogeny of prasinophyte antenna proteins: Ostreococcustauri, a case study. Molecular Biology and Evolution 22: 2217-2230.

Sposito, G., Skipper, N.T., Sutton, R., Park, S.H., Soper, A.K., Greathouse, J.A., 1999. Surface geochemistry of the clay minerals. Proc. Natl. Acad. Sci. 96, 3358-3364.

Tisdall, J.M., Oades, J.M., 1982. Organic matter and water stable aggregation in soils. Journal of Soil Science. 33, 141163

Van Bavel, C.H.M., 1949. Mean weight diameter of soil aggregates as a statistical index of aggregation. Soil Science Society of America Journal 14: 20-23.

Walkey, A., and Black, I.A. 1934. An examination of the Degtjareff method for determining soil organic matter and a proposed modification of the chromic acid titration method. Soil Science 37: 29-38.

Yoder, R.E., 1936. A direct method of aggregate analysis of soils and the study of the physical nature of erosion losses. Journal of America Society of Agronomy 28: 337-51.

Zhang, B., and Horn, R. 2001. Mechanisms of aggregate stabilization in Ultisols from subtropical China. Geoderma 99: 123145.

\section{How to cite this article:}

Krishna Chaitanya A., Shrikant Badole, Dhaneshwar Padhan, Shyam Prasad Majumder and Sreenivas Ch. 2017. Effect of Long-Term Application of Inorganic and Organics on Soil Aggregate Fractions in Double Rice Cropping System. Int.J.Curr.Microbiol.App.Sci. 6(8): 3779-3789. doi: https://doi.org/10.20546/ijcmas.2017.608.457 